Article

\title{
A Conceptual List of Indicators for Urban Planning and Management Based on Earth Observation
}

Nektarios Chrysoulakis ${ }^{1}{ }^{*}$, Christian Feigenwinter ${ }^{2}$, Dimitrios Triantakonstantis ${ }^{1}$, Igor Penyevskiy ${ }^{3}$, Abraham Tal ${ }^{4}$, Eberhard Parlow ${ }^{2}$, Guy Fleishman ${ }^{4}$, Sebnem Düzgün ${ }^{5}$, Thomas Esch ${ }^{6}$ and Mattia Marconcini ${ }^{6}$

1 Institute of Applied and Computational Mathematics, Foundation for Research and Technology_Hellas, 100 N. Plastira, Vassilika Vouton, GR 70013, Heraklion, Crete, Greece;

E-Mail: trdimitrios@gmail.com

2 Insitute for Meteorology, Climatology and Remote Sensing, University of Basel,

Klingelbergstrasse 27, 4056 Basel, Switzerland; E-Mails: christian.feigenwinter@unibas.ch (C.F.); eberhard.parlow@unibas.ch (E.P.)

3 Division Socio-Economic Planning Group, GRAD_-Inform Ltd., 35 Scherbaneva Str., 644024 Omsk, Russia; E-Mail: ipenevskii@itpgrad.ru

4 GARD Ltd., Mifratz Shlomo 2, 58498 Holon, Israel; E-Mails: abrahamtal@gmail.com (A.T.); guy_gard@bezeqint.net(G.F.)

5 Kuzgun Bilisim Ltd., ODTU Kosgeb Teknoloji Gelistirme Merkezi SEM-2 No: A6 06531, Ankara, Turkey; E-Mail: sebnemduzgun@gmail.com

6 German Aerospace Center (DLR)_DLR-DFD Oberpfaffenhofen, 82234 Wessling, Germany; E-Mails: thomas.esch@dlr.de (T.E.); Mattia.Marconcini@dlr.de (M.M.)

* Author to whom correspondence should be addressed; E-Mail: zedd2@iacm.forth.gr; Tel.: +30-2810-391762; Fax: +30-2810-391761.

Received: 23 December 2013; in revised form: 4 July 2014 / Accepted: 8 July 2014 / Published: 21 July 2014

\footnotetext{
Abstract: Sustainable development is a key component in urban studies. Earth Observation (EO) can play a valuable role in sustainable urban development and planning, since it represents a powerful data source with the potential to provide a number of relevant urban sustainability indicators. To this end, in this paper we propose a conceptual list of EO-based indicators capable of supporting urban planning and management. Three cities with different typologies, namely Basel, Switzerland; Tel Aviv, Israel; and Tyumen, Russia were selected as case studies. The EO-based indicators are defined to effectively record the physical
} 
properties of the urban environment in a diverse range of environmental sectors such as energy efficiency, air pollution and public health, water, transportation and vulnerability to hazards. The results assess the potential of EO to support the development of a set of urban environmental indicators towards sustainable urban planning and management.

Keywords: urban indicators; urban planning; Earth Observation; climate change

\section{Introduction}

Urbanization is a phenomenon of paramount importance due to direct impact on the quality of life. In 2007, urban dwellers had exceeded rural population for the first time in history and by 2030 two thirds of the world population are expected to be accommodated in urban areas [1]. Nowadays, there are conflicts in the urban planning goals towards a sustainable city arising from the different environmental, economic and political thoughts, where the motivation for planning lies in different disciplines and conceptions [2]. Thereupon, successful urban planning must take into account the three sectors: environment, economy, and policy, trying to keep a balance between them.

Recently, much effort has been spent to produce tools for the observation and analysis of the urban environment not only by the scientific community, but also by the public and private sectors. In particular, a huge number of studies has been carried out to understand and characterize urban sustainability, where numerous indicators have been proposed in urban research for a better management of cities [3,4]. Many environmental and socioeconomic variables affect urban development and the application of alternative approaches to capture these variables is a challenge $[5,6]$.

Although conventional data are useful for calculating urban indicators, they are frequently inadequate due to generalization, outdating or unavailability [7]. In this framework, Earth Observation (EO) has become an effective alternative source of geo-information for urban management and planning [8-10] and proved capable of enriching scientific knowledge with the spatial information needed to implement urban planning initiatives.

A plethora of urban products derived from EO have been introduced in urban planning applications, covering environmental and socio-economic issues. A set of urban indicators can be evaluated based on EO products. For example, a satellite radiometer records the incoming radiance at several parts of the electromagnetic spectrum. The raw EO data consists of this multispectral radiance records. By analyzing this raw EO data by means of a maximum likelihood classification method, a land cover map can be derived. This is the respective EO product that is produced from the initial EO data, by implementing this particulate analysis method. Furthermore, by selecting the pixels corresponding to built-up areas in this land cover map and by estimating their density within specific administrative boundaries, the built-up density can be derived. The latter is an EO-based indicator which has been evaluated from the land cover map (EO product) by implementing the particular analysis method that was described above. The selection of EO-based indicators should rely on the purpose of each indicator and its impact on urban sustainability [11]. Therefore, different indicators are applied in different urban environments to capture the appropriate aspects of sustainability requirements. 
The current research focuses on understanding the needs of urban planning and management that can be supported by EO data and methods. This activity was conducted in the framework of the GEOURBAN (ExploitinG Earth Observation in sUstainable uRBan plAnning \& maNagement) project [12]. GEOURBAN aimed at selecting and evaluating appropriate EO derived urban environmental indicators in three cities with different typologies and planning perspectives (i.e., Basel, Switzerland; Tel Aviv, Israel and Tyumen, Russia), according to: (a) routine urban planning and management requirements (including requirements for natural disaster risk mitigation and urban security) and (b) urban planning requirements for adaptation to climate change.

The present study describes the joint effort of GEOURBAN consortium and local stakeholders, in each of the above cities, to define the urban planning and management goals and requirements that can be supported by EO and to develop a relevant conceptual list of indicators. The objective is to produce a common set of indicators based on EO products, where they allow their transferability to other study areas without the need for in-situ modelling. This article includes the following sections: (a) description of the three study areas concerning main city characteristics (population, area, climate and urban planning system) as well as EO datasets and processing, (b) review of current understanding of urban planning and management requirements and the associated urban indicators development and (c) final discussion and conclusions.

\section{Study Areas and EO Datasets}

As mentioned above, the GEOURBAN study areas were: Tyumen, Tel Aviv and Basel. The selected case studies have the potential to support the cooperation of European, including Russia, as well as Middle East countries, exploring the different urban planning and management perspectives, as emerging in the detailed description that follows.

\subsection{Tyumen, Russia}

The city of Tyumen covers an area of 23,500 ha with a population of 580,000. It is situated on the Tura River $1700 \mathrm{~km}$ east of Moscow. The climate is humid continental with fairly warm humid summers and long cold winters (Köppen Dfb climate, [13]).

Urban Planning in Tyumen is regulated by the Town Planning Code of the Russian Federation (RF TP Code) — being the basic legal rule in the field of town planning regulation. In particular, it describes the criteria providing safe and favorable living conditions, environmental protection, protection of cultural heritage facilities and specially protected national territories. Further on, decrees enacted by the Tyumen State Duma and the Administration of the Tyumen city provide the guidelines for city specific planning. A city as a residential area is always included as a municipal entity, thus it is necessary to follow the list of issues of local value in the course of determining a regulatory benchmark. This list is set in the Federal Law No 131-FZ dated 6 October 2003 "About the general principles of the organization of local government in the Russian Federation". Town planning documentation and town planning regulation documents represent the normative basis for urban planning activities. 


\subsection{Tel Aviv, Israel}

The area of Tel Aviv is 5200 ha with population of 404,000, becoming the second most populous city in Israel. The climate is Mediterranean with warm to hot dry summers and mild rainy winters (Köppen Csa climate, [13]).

The Master Plan of Tel-Aviv is based on the Strategic Planning approach. Strategic Urban Planning combines planning concepts with strategic management procedures. It consists of a continuous cyclical process, involving: planning, implementation, monitoring and evaluation of programs, actions and urban projects, then "going back full circle", when modifications are called for, in response to changing circumstances.

The Strategic Plan for Tel-Aviv is multi-disciplinary. It is concerned with all the city's facets, the social fabric, the economy, culture, leisure, land-use, the urban fabric, transport and the environment. The planning process involved is participatory. Residents and other stakeholders are invited to express their views regarding the city's current situation, identify problems and opportunities and prioritize possible remedial courses of action. Later on, they are called upon to formulate their "vision" for the city's future. The dialogue initiated by this process helps to promote understanding among different interest groups, thus paving the way for consensus-building around specific issues.

Strategic Planning allows short-term and long-term "Action Plans" to be brought forward, while the Strategic Plan is still in preparation. Early implementation of projects and programs arising for the Plan helps to build public confidence in its merits, whilst at the same time, strengthening the Municipality's problem-solving capacity. A built-in control and follow-up mechanism helps to assess the Plan's measure of success and ability to meet its pre-set objectives. The Strategic Planning process is open and transparent and the public can follow progress on the Municipal Website and through other media.

\subsection{Basel, Switzerland}

The city of Basel counts 188,000 inhabitants while the agglomeration reaches 730,000 . The area of the city of Basel and its agglomeration is 3695 ha and 48,200 ha, respectively. The climate is oceanic with mild winters and warm and sunny summers (Köppen Cfb climate, [13]).

Urban planning in Basel is mainly performed by three city agencies in three different departments. The Agency of Cantonal and Urban Development in the presidential department counsels and supports the government council in its task to observe and evaluate all significant developments in the city and the agglomeration and to coordinate and arrange the appropriate dispositions. The Planning Office in the department of construction and traffic is responsible for urban and regional planning, for town construction and the projection in the public space and sphere. The Agency for Environment and Energy in the department of economic, social and environmental affairs is responsible for the protection of the population and the environment from harmful or disagreeable influences.

Due to the special location of Basel right at the border between Germany and France, several international institutions were established with the aim to enhance communication and coordination of the local planning authorities. The Trinational Eurodistrict Basel (TEB) was thus founded in 2007 in 
order to coordinate regional planning activities efficiently across national borders. TEB aims to reduce the negative impact of national borders and promotes to benefit from the diversity of the Basel region.

Mid-term and long-term strategies are determined by two urban planning tools, namely the Cantonal structure plan and the Legislation plan 2009-2013. The cantonal structure plan is the most important document concerning planning activities of the city of Basel and represents the mandatory instrument for planning authorities. With the strategy and the explanatory maps of the structure plan, the stage for the control of the spatial development of the next 15-20 years is set. With the Legislation plan 2009-2013, the government council defines the mid-term and long-term key aspects according to the constitutional mandate, where a sustainable development and planning is explicitly regulated by law. The combination of quantitative observation and qualitative evaluation, as defined in the legislation plan, is the base for planning and coordination of the government council's actions.

\subsection{EO Datasets and Processing}

The EO database used in GEOURBAN includes the images from the following sensors, the spatial resolution of which is shown in Table 1:

- Tyumen: Landsat-5 TM; Landsat-7 ETM+; TerraSAR-X, ASTER, ALOS;

- Tel Aviv: Landsat-5 TM; Landsat-7 ETM+; TerraSAR-X; ASTER, ALOS;

- Basel: Landsat-4 TM; Landsat-5 TM; Landsat-7 ETM+; Quickbird, TerraSAR-X, ASTER; ALOS, as well as airborne hyperspectral (APEX) observations.

The above datasets were used to derive EO products, like land cover, digital elevation model, impervious areas fraction, aerosol optical depth, surface albedo and emissivity, etc. Such products were derived in GEOURBAN by employing state-of-the-art analysis techniques [14-24]. For example, for land cover mapping, maximum likelihood classifiers and support vector machines were used; for imperviousness and land surface emissivity, linear spectral unmixing techniques were employed; for surface broadband albedo conversion methods from narrowband spectral albedos were used; for surface temperature, single channel and split window algorithms were utilized; for building volume and density estimation, a specific processing of the spaceborn radar backscattering amplitude were carried out to extract suitable texture information. Finally, the various EO products were combined by means of spatial analysis to derive meaning for urban planning and management indicators, following the conceptual list that is discussed in this study. 
Table 1. Routine requirements and the associated Earth Observation (EO)-based products and indicators.

\begin{tabular}{|c|c|c|c|c|c|}
\hline Sector & $\begin{array}{c}\text { Topic } \\
\text { (Processes/Mechanisms) }\end{array}$ & Action & $\begin{array}{c}\text { Indicators/Parameters } \\
\text { with Relevance to EO }\end{array}$ & EO Sensors & $\begin{array}{c}\text { Spatial } \\
\text { Resolution }\end{array}$ \\
\hline $\begin{array}{l}\text { Air pollution and } \\
\text { public health }\end{array}$ & $\begin{array}{l}\text { Emissions by industry, } \\
\text { traffic and domestic } \\
\text { heating (NOx, SOx, CO, } \\
\left.\mathrm{O}_{3}, \mathrm{PM}, \mathrm{VOC}\right)\end{array}$ & $\begin{array}{l}\text { Reduction of emissions by technical measures, } \\
\text { traffic regulations, toll roads, congestion charges, } \\
\text { emission scenarios, low emission standards for } \\
\text { vehicles, public transportation support systems, } \\
\text { pollution monitoring, identification and care for } \\
\text { vulnerable people }\end{array}$ & $\begin{array}{l}\text { AOT, Surface topography } \\
\text { (DTM), building structure } \\
\text { (DSM), built-up density, } \\
\text { population distribution as } \\
\text { input for dispersion models } \\
\text { and emission scenarios }\end{array}$ & $\begin{array}{l}\text { MODIS } \\
\text { ASTER } \\
\text { Landsat } \\
\text { WorldView }\end{array}$ & $\begin{array}{l}10 \mathrm{~km} \\
30 \mathrm{~m} \\
30 \mathrm{~m}\end{array}$ \\
\hline Energy efficiency & $\begin{array}{l}\text { Inefficient energy use as } \\
\text { a main contributor to air } \\
\text { pollution, UHI and } \\
\text { thermal discomfort }\end{array}$ & $\begin{array}{l}\text { Support of energy efficient systems for } \\
\text { heating/cooling facilities, renewable energy } \\
\text { production, building isolation, measures for } \\
\mathrm{CO}_{2} \text { reduction }\end{array}$ & $\begin{array}{l}\text { Building structure DSM, } \\
\text { albedo, emissivity }\end{array}$ & Landsat & $30 \mathrm{~m}$ \\
\hline $\begin{array}{l}\text { Transportation } \\
\text { and mobility, } \\
\text { accessibility }\end{array}$ & $\begin{array}{l}\text { Conflict of interest } \\
\text { between city authorities, } \\
\text { policy, economy and } \\
\text { private interests }\end{array}$ & $\begin{array}{l}\text { Reduction of private traffic, support of public } \\
\text { transportation and non-motorized traffic, toll } \\
\text { roads, traffic restrictions by structural measures }\end{array}$ & $\begin{array}{l}\text { Traffic (street and railway) } \\
\text { network, lines of } \\
\text { communication }\end{array}$ & & \\
\hline Thermal comfort & $\begin{array}{l}\text { Higher average } \\
\text { temperatures in urban } \\
\text { areas especially during the } \\
\text { night compared to the rural } \\
\text { surroundings (UHI) }\end{array}$ & $\begin{array}{l}\text { Increasing the fraction of vegetated/green areas } \\
\text { at the expense of impervious surfaces, increasing } \\
\text { the fraction of shaded areas, reservation and } \\
\text { clearing/creating of fresh air corridors, increasing } \\
\text { surface albedo ("cool roofs"), sun shading of } \\
\text { buildings and windows in order to decrease the } \\
\text { storage of heat during daytime, planning, } \\
\text { technical and construction measures }\end{array}$ & $\begin{array}{l}\text { Surface temperatures, } \\
\text { urban surface materials, } \\
\text { surface albedo, surface } \\
\text { emissivity, built up density, } \\
\text { fractional land cover, } \\
\text { imperviousness/surface } \\
\text { sealing }\end{array}$ & $\begin{array}{c}\text { MODIS } \\
\text { Landsat } \\
\text { TerraSar-X } \\
\text { RadipEye } \\
\text { WorldView }\end{array}$ & $\begin{array}{c}10 \mathrm{~km} \\
30 \mathrm{~m} \\
1,3,16 \mathrm{~m} \\
5 \mathrm{~m} \\
0.46 \\
1.84 \mathrm{~m}\end{array}$ \\
\hline Urban green & $\begin{array}{l}\text { Reduced green and open } \\
\text { spaces due to urban } \\
\text { growth, environmental } \\
\text { degradation due to } \\
\text { increased urbanization }\end{array}$ & $\begin{array}{l}\text { Conservation of urban green (parks, trees), } \\
\text { increase of vegetated/green areas } \\
\text { (e.g., vegetated roofs), urban farming }\end{array}$ & $\begin{array}{l}\text { Land cover, urban } \\
\text { surface materials, } \\
\text { vegetation indices, } \\
\text { fractional land cover }\end{array}$ & Landsat & $30 \mathrm{~m}$ \\
\hline
\end{tabular}


Table 1. Cont

\begin{tabular}{|c|c|c|c|c|c|}
\hline Sector & $\begin{array}{c}\text { Topic } \\
\text { (Processes/Mechanisms) } \\
\end{array}$ & Action & $\begin{array}{c}\text { Indicators/Parameters } \\
\text { with Relevance to EO }\end{array}$ & EO Sensors & $\begin{array}{c}\text { Spatial } \\
\text { Resolution }\end{array}$ \\
\hline $\begin{array}{l}\text { Territorial } \\
\text { development }\end{array}$ & $\begin{array}{l}\text { Settlement development, } \\
\text { urban sprawl, industrial } \\
\text { land consumption, } \\
\text { urban land use, } \\
\text { population growth }\end{array}$ & $\begin{array}{l}\text { Forceful application of legislation and } \\
\text { existing planning instruments, evaluation of } \\
\text { potential areas for expansion, promotion of } \\
\text { high-density housing }\end{array}$ & $\begin{array}{l}\text { built up density, land cover, } \\
\text { land cover change }\end{array}$ & Landsat & $30 \mathrm{~m}$ \\
\hline $\begin{array}{l}\text { Vulnerability to } \\
\text { environmental } \\
\text { hazards }\end{array}$ & $\begin{array}{l}\text { floods/droughts, } \\
\text { air contamination, fires, } \\
\text { heat waves }\end{array}$ & $\begin{array}{l}\text { Reduction of risk exposure, improvement of } \\
\text { crisis management by (near) real time } \\
\text { monitoring, dispersion models, evacuation plans, } \\
\text { early-warning systems, protection and } \\
\text { accessibility of critical infrastructure, } \\
\text { expansion/creation of flooding zones }\end{array}$ & $\begin{array}{l}\text { Surface topography (DTM), } \\
\text { built-up density (DSM), } \\
\text { population distribution, } \\
\text { input for dispersion models, } \\
\text { critical infrastructure }\end{array}$ & ASTER & $30 \mathrm{~m}$ \\
\hline
\end{tabular}

Table 2. Requirements for adaptation to climate change and the associated indicators with relevance to EO data.

\begin{tabular}{llll}
\hline \multicolumn{1}{c}{ Sector } & \multicolumn{1}{c}{ Topic (Processes/Mechanisms) } & \multicolumn{1}{c}{ Action } & \multicolumn{1}{c}{$\begin{array}{c}\text { Indicators/Parameters with } \\
\text { Relevance to EO }\end{array}$} \\
\hline \multirow{3}{*}{$\begin{array}{l}\text { Marine and inland } \\
\text { water ecosystems }\end{array}$} & $\begin{array}{l}\text { Increasing water temperatures with negative } \\
\text { influence on ecology, enhanced effect by use } \\
\text { for cooling industrial facilities, flooding (river } \\
\text { and coastal), droughts }\end{array}$ & $\begin{array}{l}\text { Revitalization of water ecosystems, reduction of } \\
\text { industrial heat input by technical measures, } \\
\text { sustainable water management, reduction of } \\
\text { waste-water amount }\end{array}$ & $\begin{array}{l}\text { sea/water surface temperatures and } \\
\text { temperature change, land cover, land } \\
\text { cover change (floodwater, low-water) }\end{array}$ \\
\hline \multirow{6}{*}{$\begin{array}{l}\text { Ground water } \\
(\mathrm{GW})\end{array}$} & $\begin{array}{l}\text { GW regeneration with negative influence } \\
\text { on GW quality and availability, changes } \\
\text { of GW regeneration with changing } \\
\text { precipitation patterns }\end{array}$ & $\begin{array}{l}\text { Evaluation of the relevant anthropogenic and } \\
\text { natural factors (e.g., by monitoring, modelling) } \\
\text { and development of strategies for the solution of } \\
\text { conflicts of interest; adaption of rules for } \\
\text { construction and GW use }\end{array}$ & $\begin{array}{l}\text { sea/water surface temperatures and } \\
\text { temperature change, land cover, land } \\
\text { cover change }\end{array}$ \\
\hline
\end{tabular}


Table 2. Cont.

\begin{tabular}{|c|c|c|c|}
\hline Sector & Topic (Processes/Mechanisms) & Action & $\begin{array}{c}\text { Indicators/Parameters with } \\
\text { Relevance to EO } \\
\end{array}$ \\
\hline $\begin{array}{l}\text { Drinking water } \\
\text { (DW) }\end{array}$ & $\begin{array}{l}\text { Increasing extreme weather events and natural } \\
\text { hazards (droughts, heat wave, heavy } \\
\text { precipitation events causing floods and storm } \\
\text { surge, etc.) have significant influence on the } \\
\text { availability and the quality of DW }\end{array}$ & $\begin{array}{l}\text { Technical measures (changing the location of DW } \\
\text { abstraction), renovation and modernisation of } \\
\text { water engineering infrastructures }\end{array}$ & $\begin{array}{l}\text { Population distribution, land cover, land } \\
\text { cover change }\end{array}$ \\
\hline Urban climate & $\begin{array}{l}\text { Urban heat island (UHI) intensity and heat } \\
\text { waves are expected to increase in the future } \\
\text { with high impact on urban climate }\end{array}$ & $\begin{array}{l}\text { Increasing the fraction of vegetated/green areas } \\
\text { at the expense of impervious surfaces, increasing } \\
\text { the fraction of shaded areas, reservation and } \\
\text { clearing/creating of fresh air Corridors, increasing } \\
\text { surface albedo ("cool roofs"), sun shading of } \\
\text { buildings and windows in order to decrease the } \\
\text { storage of heat during daytime, planning, } \\
\text { technical and construction measures }\end{array}$ & $\begin{array}{l}\text { surface temperatures, urban surface } \\
\text { materials, surface albedo, built-up } \\
\text { density, fractional land cover, } \\
\text { imperviousness/surface sealing }\end{array}$ \\
\hline Air quality & $\begin{array}{l}\text { Increasing temperatures will likely cause } \\
\text { higher ground level ozone concentrations }\end{array}$ & $\begin{array}{l}\text { reservation and clearing/creating of fresh air } \\
\text { corridors, reducing emissions of primary } \\
\text { pollutants }\left(\mathrm{NO}_{\mathrm{x}}, \mathrm{VOC}\right)\end{array}$ & $\begin{array}{l}\text { Surface topography (DTM), building } \\
\text { structure (DSM), built-up density, as } \\
\text { input for dispersion models }\end{array}$ \\
\hline Health & $\begin{array}{l}\text { Refer to urban climate and air quality. } \\
\text { Increased heat stress and increased air } \\
\text { pollution will mainly affect infants and young } \\
\text { children, seniors, physically and/or mentally } \\
\text { sick persons and socially isolated persons }\end{array}$ & $\begin{array}{l}\text { Early-warning systems for heat waves, hazardous } \\
\text { air contamination and industrial disasters, } \\
\text { information about arrangements and behavior } \\
\text { recommendations, special instructions and action } \\
\text { plans for highly affected institutions (care and } \\
\text { residential nursing homes, hospitals, schools) } \\
\text { and people }\end{array}$ & Refer to urban climate and air quality \\
\hline
\end{tabular}




\section{Methodology and Results}

In the present study, the urban development management goals and requirements were provided by local authorities through a Community of Practice (CoP) approach [25]. The CoP participatory method consists of a body of local stakeholders and scientists that meet on a regular basis in order to learn from each other. One of the main purposes of the CoP is to acknowledge the different stakeholders' perceptions into the indicator development. Therefore, the users of GEOURBAN (local authorities, urban planners and decision makers) were involved in the project via a CoP approach. The participation to the CoP body was 17 persons in Basel, 28 persons in Tyumen and 10 persons in Tel Aviv meetings. After determining these urban planning and management goals and requirements, a conceptual list of urban indicators based on EO was developed, focusing either on routine urban planning and management requirements, or on requirements for adaptation to climate change. The EO-based indicators produced are disaggregated indicators. They were produced under pixel-based processing, where products from EO data were appropriately analyzed. Therefore, the spatial resolution of indicators is the spatial resolution of the corresponding product.

\subsection{Routine Requirements and the Associated EO Indicators}

The routine requirements listed in Table 1 were compiled combining the goals of urban planning institutions and the outcome of the CoP meetings. The topics were selected in the light of the main objective of our research, which is to support urban planning by tailoring geo-information products derived from EO data. Topics that are unlikely to be supported by EO data were ignored.

As Table 1 indicates, planning actions and strategies can be effectively supported by using EO-based geo-information products which already proved effective for retrieving suitable indicators for urban management and planning (e.g., they can be used to estimate urban quality of life in terms of air and water pollution or energy efficiency). Applying the appropriate methodology to the available satellite images, several urban parameters can be successfully retrieved. In this framework, the most relevant urban geo-information products for different sectors are extensively described below.

\subsubsection{Air Pollution and Public Health}

Air pollution and public health depend on emissions of industry, as well as traffic and domestic heating. Planning actions should be adopted for a sustainable management (Table 2). In such context, key indicators are: AOT (Atmospheric Optical Thickness), surface topography (characterized by means of digital terrain models - DTM) and building structure (derived by differencing corresponding DTM and digital surface models_-DSM) as well as population distribution.

\section{Atmospheric Optical Thickness (AOT)}

Data from high resolution sensors, such as Landsat and SPOT, can be used to calculate atmospheric transparent indicators, such as AOT [26], which can be used to derive PM10 and/or PM2.5 spatial distribution [27] and hence to derive, in combination with population distribution and building structure, an estimation of exposure. Daily AOT products can be also derived by low resolution sensors [20]. In Figure 1, an AOT map for the Basel study area derived by MODIS (2012 image) is given. 
Figure 1. AOT map produced by MODIS (2012 image) for Basel study area.

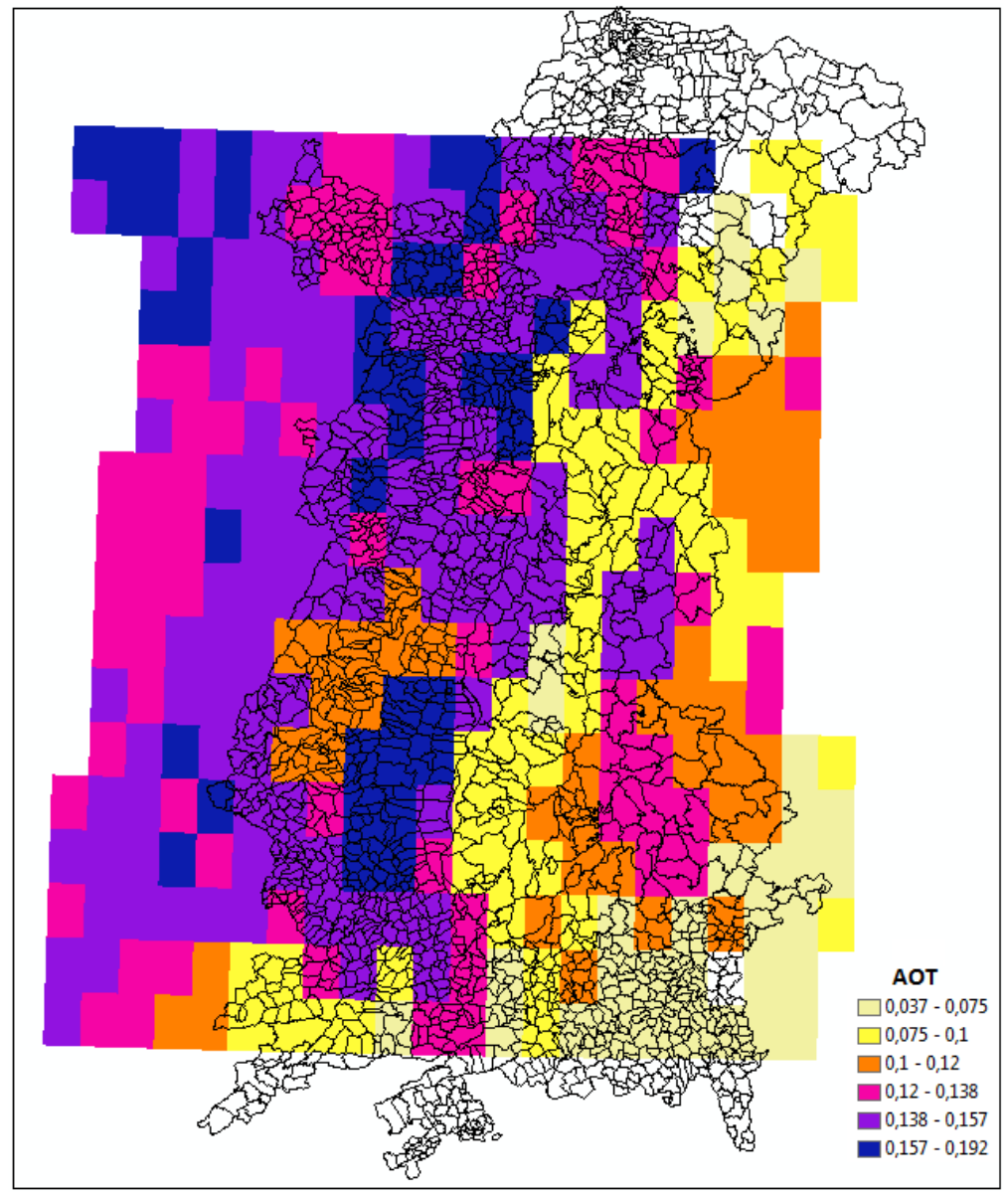

Surface Topography and Building Structure

Satellite images are potentially the most advantageous data source for describing surface topography (based on DTM) and building structure (based on both DTM and DSM). DTM characterizes terrain surface, while DSM accounts for terrain discontinuities, where man-made structures can be distinguished. The ease of periodical acquisition and feasibility of automation are the main components among remote sensing advantages [28]. Very high resolution images, such as IKONOS and QuickBird with a spatial resolution below $1 \mathrm{~m}$ in the panchromatic mode and $4 \mathrm{~m}$ in the multispectral mode or GeoEye-1, WorldView-1, and RapidEye with $5 \mathrm{~m}$ or an even finer spatial resolution, have started a new era in surface digital mapping. Their capability to obtain stereo images from the same orbital pass is due to change of the viewing angle in one orbit [29]. Therefore, a DTM can be generated by overlapping two stereo images, taken from the same area at slightly different positions.

\section{Population Distribution}

Population distribution is another urban indicator which can be effectively used to estimate air pollution, public health or the vulnerability to environmental hazards. Population estimation using conventional census data is time-consuming, costly, and difficult to update. Moreover, the census interval is usually inadequate for urban planning, resource management and service allocation. In contrary, many statistical and interpolation methods have been proposed as alternative opportunities 
for population estimation [30]. These methods do not directly measure the population distribution, because ancillary field survey census data is needed. Therefore, the integration of satellite images with census data (i.e., a priority research task in many applications) can improve the population estimation [31,32].

\subsubsection{Energy Efficiency}

Energy efficiency focuses on reducing energy usage - a main factor of air pollution, urban heat island and climate change. Cities are responsible for $76 \%$ of global final energy consumption and about $71 \%$ of energy related $\mathrm{CO}_{2}$ emissions [33]. An improvement of energy efficiency is a challenge for addressing these issues, and would trigger many benefits including a reduction in the emissions of greenhouse gases and other pollutants, as well as lower costs of equipment and process technologies. Actions towards this objective include renewable energy production (e.g., sun, wind, water, geothermal and biomass sources) and building insulation. EO urban parameters related to energy efficiency are building structure, albedo and emissivity [34] (Table 2).

\section{Radiation Field}

The total energy consumed by buildings in Europe reaches 20\% [35]. The estimation of solar radiation incident on the Earth's surface is useful for urban planning (e.g., for construction of energy-efficient buildings). Solar radiation can be estimated by satellite data applying statistical modeling and physical modeling techniques [36]. The sky view factor can be derived from DSM as per [37]. Several methods have been developed to estimate surface albedo [15], emissivity [19] and radiation balance [14] from high resolution satellite data.

\subsubsection{Transportation and Mobility, Accessibility}

Transportation is increasing and has now reached a crisis level. $\mathrm{CO}_{2}$ emissions from transportation are approximately $23 \%$ of global fossil fuel emissions, while this sector is responsible for approximately $15 \%$ of the total greenhouse gas emissions [38]. Reducing private transport, improving public transport and developing non-motorized transport are some urban planning actions for a sustainable transportation. Urban indicators such as traffic network can be retrieved by EO data.

\section{Traffic Network}

Roads extraction by remote sensing methods has been a research task in many applications such as transportation modeling, accessibility services and car navigation. Remote sensing imagery is a promising data source for the identification of fine-scale features such as buildings and roads. Semi-automatic and automatic methods can be used for the road network extraction and updating. In the former case, some extra information such as seed points with directions are provided to an algorithm, which connects them using path criteria [39]. In the latter case, the speed of road extraction is improved, since human intervention is limited. Robust and precise road extraction can be achieved by fusing information from different image sources [40]. Therefore, earth observation data can indirectly support analysis of mobility and accessibility by providing an ancillary data layer of traffic network. This data 
can be updated routinely and at a low cost, given the improved temporal resolution of the current satellite systems.

\subsubsection{Thermal Comfort}

Thermal comfort is one of the main parameters affecting human life in an urban environment. The surface urban heat island intensity is a measurement of thermal comfort and can be defined as the phenomenon where mean air temperature in urban areas is higher than in surrounding rural areas. It is mainly related to density of buildings, green spaces and anthropogenic heat. Related actions include: increase of green spaces, creation of fresh air corridors, and cool roofs (high solar reflectance). EO urban indicators, suitable for addressing thermal comfort, are land surface temperature, surface albedo and built-up density or imperviousness.

\section{Land Surface Temperature (LST)}

LST is an important variable in energy fluxes between Earth surface and air. Remote sensing thermal infrared data have been widely used in urban studies in order to estimate LST [15,41-43]. Many multispectral sensors are able to measure the energy emitted from the Earth's surface in the thermal infrared portion of the electromagnetic spectrum and thus, LST can be calculated. LST calculation depends on the effective estimation of surface emissivity, which is controlled by several factors such as water, plants, surface roughness, etc. [43]. In Figure 2, an example of MODIS derived nighttime LST distribution of Basel is presented.

Figure 2. Average monthly land surface distribution (LST) (Kelvin), based on time series analysis of 13 years in Basel.
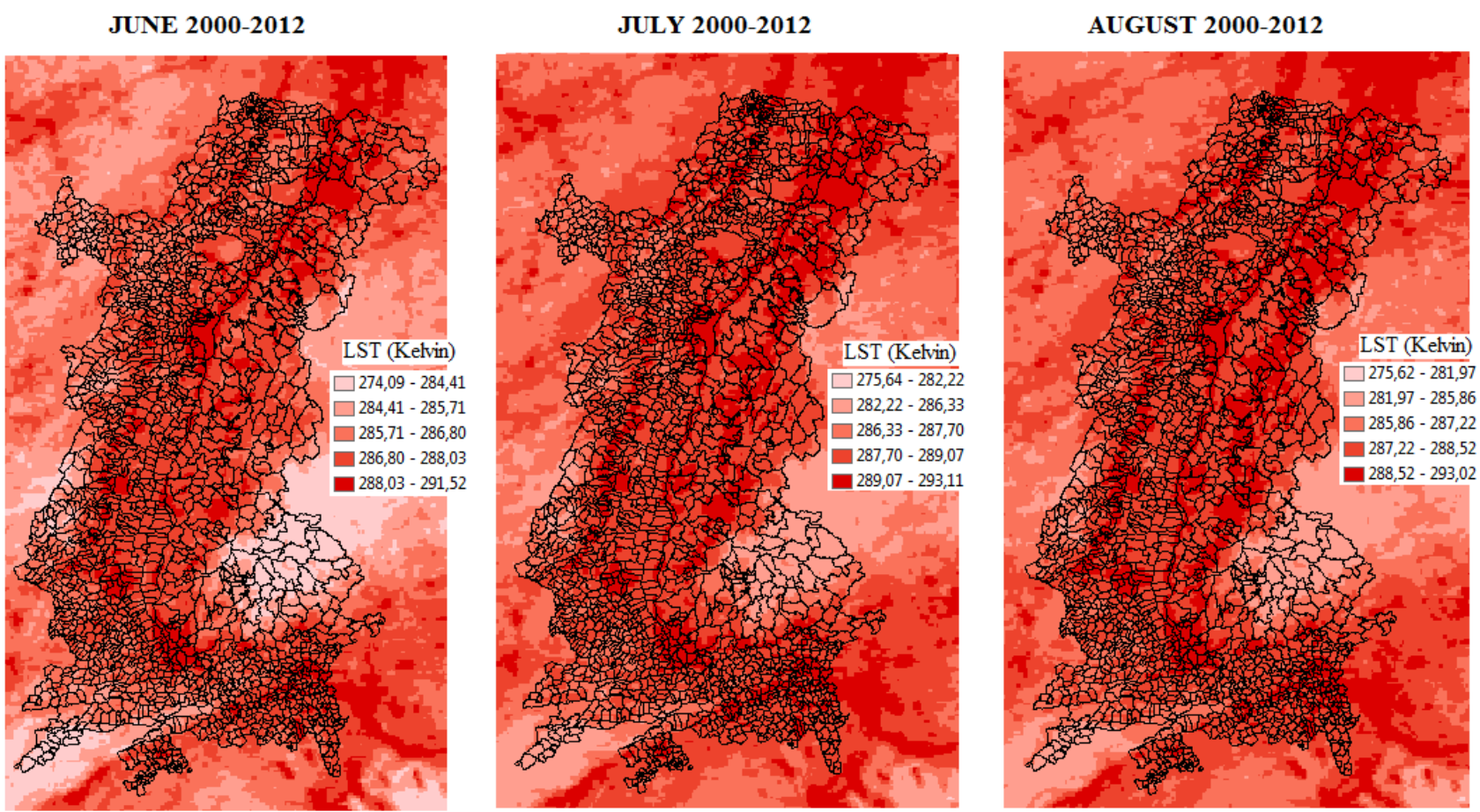
Surface Albedo

The spectral albedo of a plane surface is defined as the ratio between the hemispherical integrals of the up-welling (reflected) spectral radiance and the down-welling spectral radiance weighted by the cosine of the angle between the respective reference direction and the surface normal. In general, the spectral albedo of non-Lambertian surfaces depends on the angular distribution of the incident radiation - which in turn depends on the concentration and properties of scattering agents (e.g., aerosols) in the atmosphere and in particular on the presence of clouds. When multiple satellite observations are available, the spectral albedo can be estimated taking into account the surface anisotropy [44]. If a single image is available (high spatial resolution) approximations are needed $[15,45]$. The broadband albedo can be estimated from spectral albedos [46].

Built-Up Density-Imperviousness

Many studies have examined the urban land use extraction from satellite images. More specifically, different techniques have used textural information, neural networks and object-oriented approaches [47-49]. Moreover, recent research has applied per-pixel image classification, sub-pixel classification and decision tree modeling to built-up area discrimination [10,50]. However, because of the difficulty in discriminating the urban from suburban landscapes, impervious surface extraction is still a research challenge. Nevertheless, built-up area density is considered an important urban indicator and is highly applied in urban and environmental planning. In Figure 3, the built-up densities for Basel, Tyumen and Tel Aviv are displayed.

\subsubsection{Urban Green}

Developing and planning green spaces is of great importance in urban planning because it reduces the urban heat island, cleans urban air and absorbs $\mathrm{CO}_{2}$. Preservation of green areas is a target goal for urban planning initiatives. Land cover and vegetation indices are crucial EO urban indicators, which contribute to sustainable urban planning and management.

\section{Land Cover}

Urban sprawl monitoring and modeling are considered vital for long-term urban planning [51]. EO can play an important role in a balanced urban development because it is a useful tool for mapping urban land cover as well as monitoring urban land cover changes over time. Because of the large spatial and spectral variability of urban surface, classification methods are continuously evolving and further improving the discrimination accuracy has become a scientific goal [52]. Although the manual process of digitizing is the most accurate technique of extracting impervious surface, it is not recommended because it is time-consuming and costly. Thereupon, several classification methods have been proposed, which can generally be divided in three main categories: (a) unsupervised methods, where pixels are clustered into a number of classes according to their statistical indices [53], (b) supervised methods, where labeled information available a priori is used [54,55], and (c) transductive and semi-supervised methods, where labeled and unlabeled information is jointly 
exploited to improve classification results [56-58]. The land use-land cover map for Tel Aviv produced by supervised classification is presented in Figure 4.

Figure 3. (a) Built-up density in Basel, Switzerland; (b) Built-up density in Tyumen, Russia; (c) Built-up density in Tel Aviv, Israel.
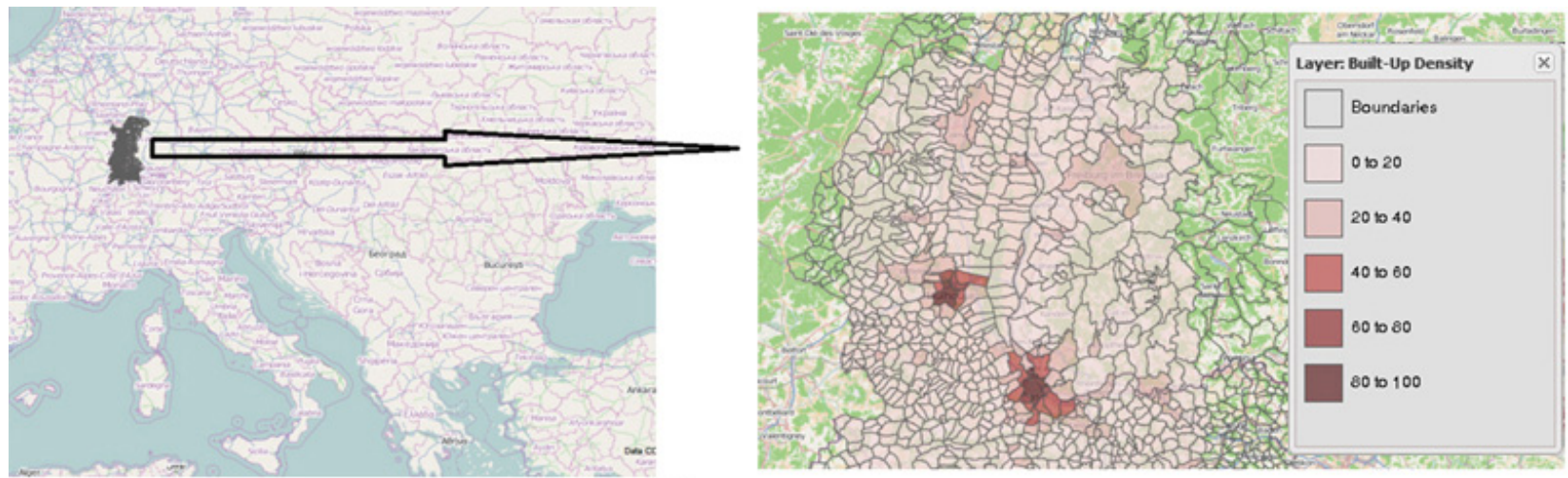

(a)
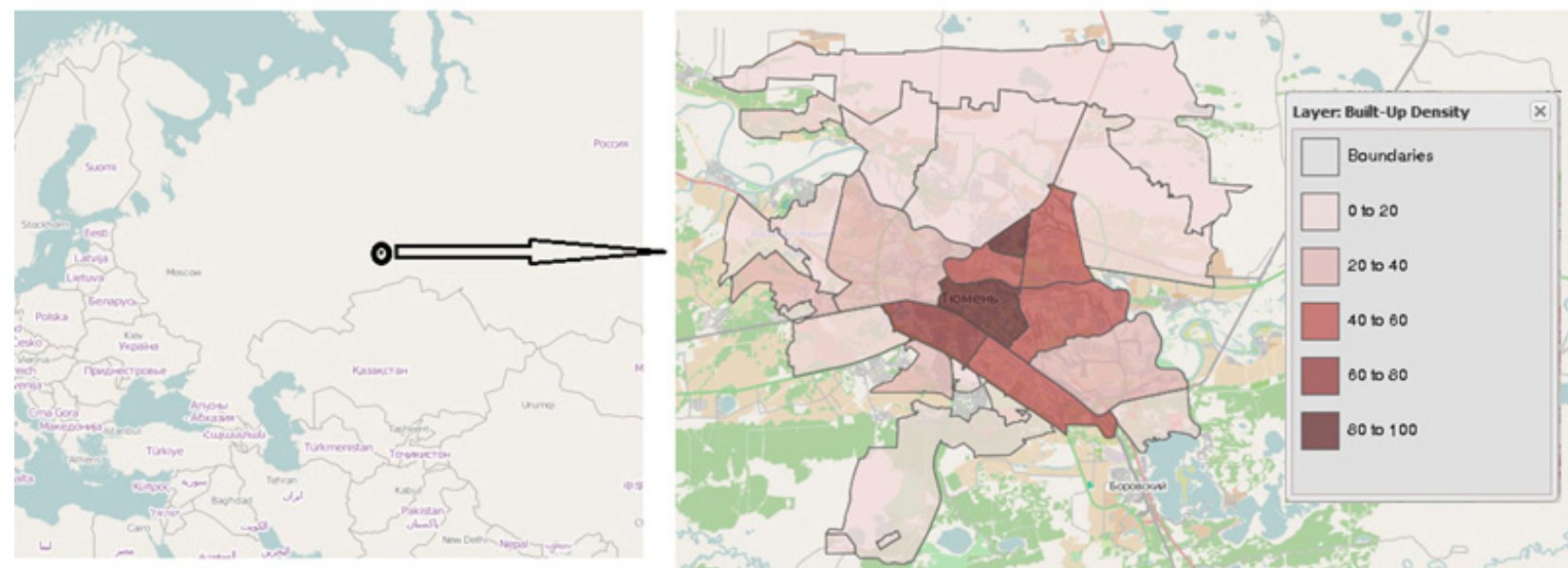

(b)
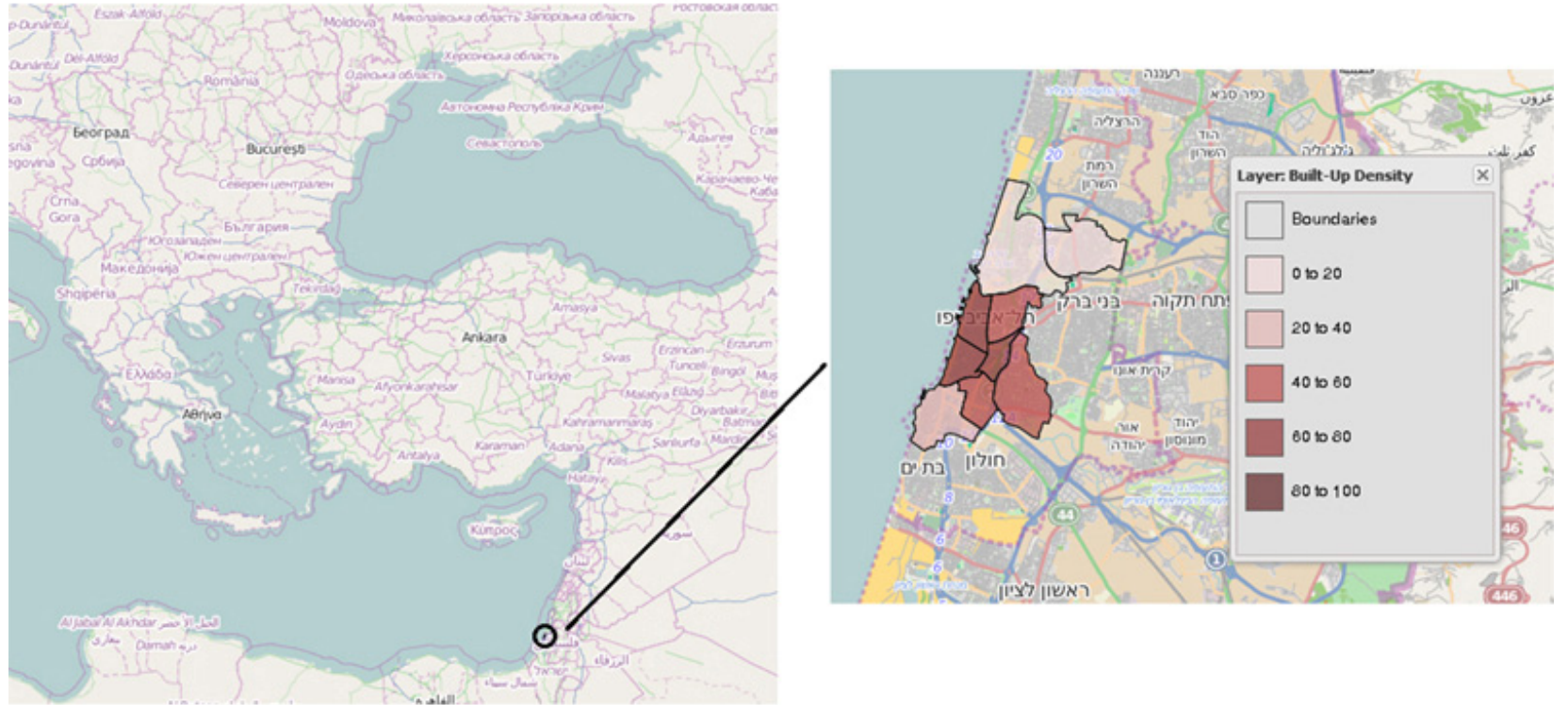

(c) 
Figure 4. Land use map for Tel Aviv, Israel.

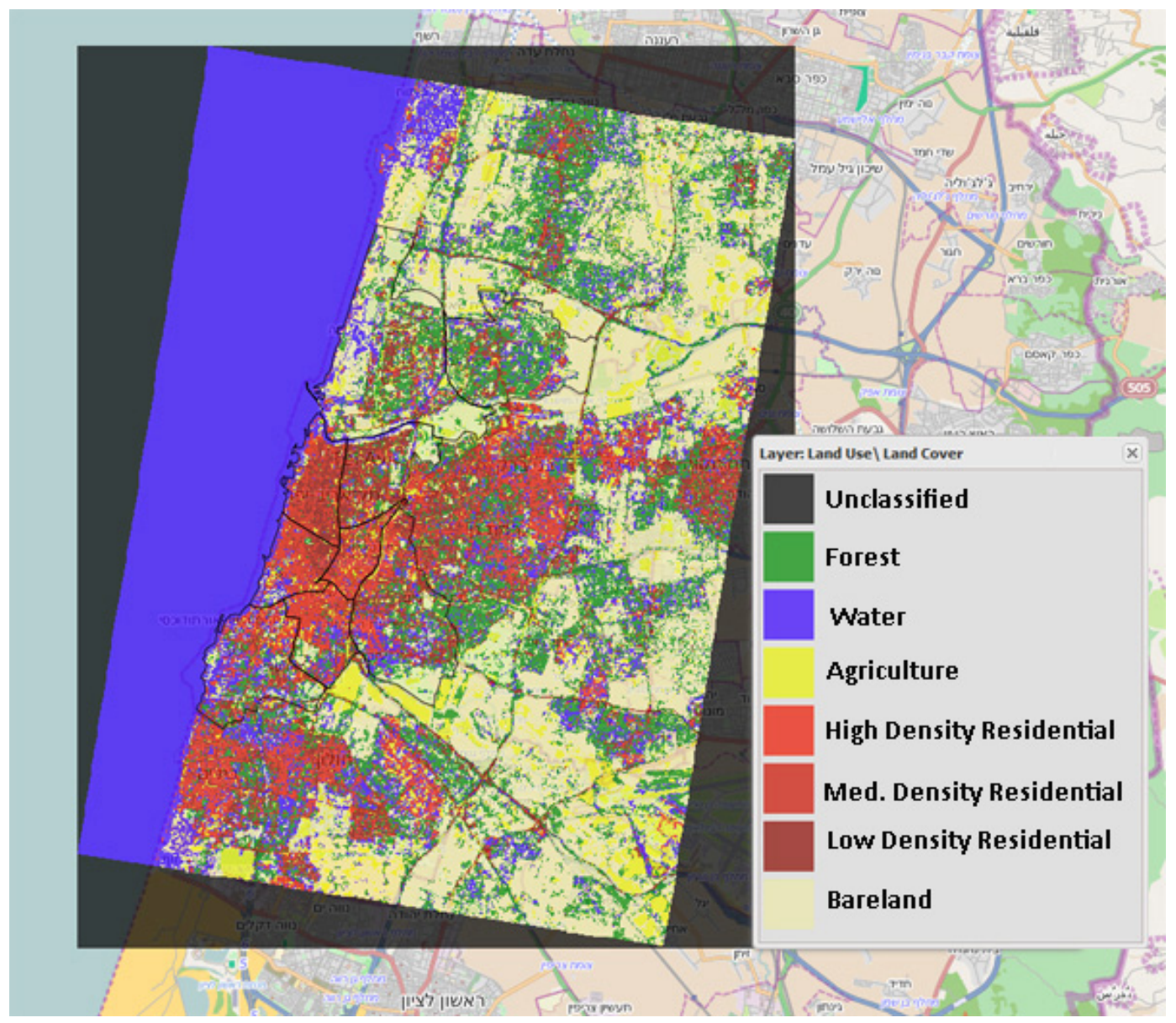

Vegetation Indices

The spatio-temporal distribution of vegetation is a fundamental variable in urban planning because vegetation affects the energy fluxes in the Earth's surface by absorption or reflection of the solar radiation [59]. The use of vegetation indices is the most common approach for vegetation monitoring. In this context, a widely used index is the NDVI (Normalized Difference Vegetation Index), in which the visible and near-infrared reflectance bands are appropriately combined. Other indices, such as SRI (Simple Ration Index, the division of NIR by Red spectral bands) and ARVI (Atmospherically Resistant Vegetation Index, which minimizes atmospheric effects) can be also applied in vegetation mapping [60].

\subsubsection{Territorial Development}

Territorial development refers to spatial distribution of urban and natural features, where human activity plays a crucial role in maintaining sustainability. It relies on the analysis of natural and artificial resources and socio-economic needs for a given territory. Moreover, it is based on actions and strategies required to manage and plan urban land use as well as evaluate potential areas for urban expansion. Built-up density, land cover and land cover change can successfully become urban indicators, derived from EO data. 


\subsubsection{Vulnerability to Environmental Hazards}

Urban settlements have become extremely vulnerable to environmental hazards due to increasing housing density, material assets and different socio-economic conditions. Environmental hazards such as winds, fires, floods/droughts, air contamination, landslides and earthquakes can be included in urban planning by predicting and evaluating their potential to occur. Planning actions, such as real time monitoring, dispersion models, and protection and accessibility of critical infrastructure, focus on minimizing the effects of hazards in advance. Finally, EO urban indicators which can address the vulnerability to environmental hazards are: surface topography, built-up density and population distribution $[32,61,62]$.

\subsection{Requirements for Adaptation to Climate Change and the Associated EO Indicators}

Cities are highly vulnerable to severe weather events which are expected to become more frequent and intense in the light of the present climate change [63]. Planning authorities at all political levels need to consider adaptation and mitigation measures in order to make their city resilient against these impacts [64]. Several topics referring to the future adaption of urban planning with respect to climate change are closely related to routine requirements, but will attract increased interest and significance with ongoing climate change with its main expected impacts like the increased number of flooding/drought events, heat waves and water scarcity as a consequence of rising temperatures, changing precipitation patterns and rising sea levels. Table 2 lists the most significant sectors, activities, priorities and their relevance to EO in GEOURBAN case studies.

Towards mitigation and adaptation strategies, EO data can successfully provide relevant indicators in order to better estimate the actual needs for a sustainable urban development. Increase of greenhouse gas emissions leads to an increase of air and water temperatures. During the last 100 years, the sea level has risen 10-20 cm and over the next 100 years this value is expected to further increase due to climate change [65]. As a result, it is more likely that severe events (e.g., floods, heat waves) might occur, with a negative impact on human life. Moreover, along with other weather events influenced by climate change such as strong hail and storms, much attention must be paid to safe and secure constructions of buildings and other infrastructure. The rising sea level could supply chemicals and pathogens to aquifers due to salt water intrusions [66]. Thereupon, water quality is proven to be very sensitive to environmental changes with negative impacts on human health. Urban indicators such as population distribution and land cover are important drivers for a prosperous water management.

Increasing temperature of marine or inland water causes negative impacts on ecology and urban ecosystems. The estimation of sea/water temperatures is an urban indicator, which can be measured by calculating the thermal emission of the water bodies [67]. The accuracy of sea surface temperature measurements achieved by EO methods is quite reasonable, ranging from $0.3-0.5 \mathrm{~K}$, compared with temperatures retrieved by conventional methods [67].

Climate change may also intensify urban heat islands with impact on air quality, heat stress and human deaths [68]. Heat waves are also more frequently expected [69,70]. Increasing the fraction of vegetated areas, reservation and clearing/creating fresh air corridors are some actions, which could improve urban climate. Urban indicators such as surface temperatures, albedo, built-up density, fractional 
land cover and imperviousness/surface sealing can be used to support urban management and planning. Fractional land cover refers to the proportion of an area which is covered by a specific land cover type. Many mapping techniques have been applied to estimate fractional land cover from remote sensing imagery, such as linear modeling, spectral unmixing models and physical models $[71,72]$.

When the surface temperature increases, the concentration of ozone increases as well, influencing air quality. Reservation of fresh air corridors and reducing pollutant emissions are needed for a better air quality. Urban climate and air quality are responsible for human health, mainly affecting young children, seniors and sick persons.

EO-based indicators have also high potential for supporting "land-based mitigation", defined as land surface changes producing a modification in urban energy water and carbon exchanges towards slowing the pace of warming. Land-based mitigation complements conventional emissions-based mitigation through addressing the regional to local-scale drivers of climate change that are often the principal driver of ongoing warming trends at these scales $[69,73,74]$. The land-use planning activities of local/regional governments may therefore provide the most direct regulatory means of managing urban energy water and carbon exchanges towards a sustainable urban metabolism [5], so as to minimize land-based climate forcing.

\section{Discussions and Conclusions}

EO provides new opportunities for urban planning and management. The monitoring of urbanization, a phenomenon with high impact on a human's life, is substantially favored by satellite data. For instance, urban mapping and monitoring, socioeconomic variables (population density), and climate characteristics (air and water quality) are some applications, in which EO data can play a significant role. Urban planning and management can enhance initiatives in order to design the appropriate framework of sustainable activities. The contribution of EO to the implementation of these activities is of high importance, because of increasing availability and improved processing and analysis capabilities. In this paper, we explored the needs of urban planning and management that can be supported by EO. We focused on both routine requirements (including requirements for natural disaster risk mitigation and urban security) and requirements related to adaptation to climate change.

For handling these requirements, a conceptual list of urban environmental indicators was proposed. These indicators can be evaluated from the EO products that were selected in this study. Information on state of the art methods that can be employed to generate the above EO products from satellite observations at several scales was also given.

The proposed EO-based indicators have the potential to support assessments of urban environmental quality and the quality of life and to provide useful information to urban planners and decision makers that can be exploited in sustainable urban planning. Although field data are important to any climate change mitigation and adaptation activity, EO indicators can support urban planning, by saving time, reducing costs and providing higher flexibility. Therefore, EO has the potential to play an important role in managing land use, designing urban environment, including transportation networks and sustaining development of economic, social and environmental initiatives.

Although the development of indicators was implemented in three study areas, common approaches in handling urban environments can be established in order to achieve sustainable living conditions. 
These approaches refer to the application of the appropriate methodologies in EO data so as to retrieve urban indicators, suitable to describe air pollution and public health, energy efficiency, transportation accessibility, thermal comfort, urban green, and vulnerability to natural hazards. Moreover, the impact of these urban environment characteristics in climate change can be also assessed.

The added value of satellite technology in comparison with traditional ways of providing urban geospatial information lies in the fact that it can provide alternative tools for urban planning by supporting the development of urban environmental indicators under a low cost, efficient, precise and non-time-consuming framework. With their high spatial resolution and revisiting times, the potential of the contemporary satellite missions to support a wide range of such indicators is high. Thus, as Figures 1-4 show, the impact of EO-based indicators for operational urban planning and management is high, because they provide a framework of spatial tools, easily retrievable from EO data and adaptable for urban planners' needs. For example, built-up density, AOT and LST can support urban plans by providing useful information related to urban-rural interaction (urban sprawl), to urban health (air quality) and to urban climate (urban heat island), respectively, meeting operational urban planning requirements that could be alternatively supported only by a dense (given the urban surface anisotropy) network of in-situ stations measuring the above parameters; such sensor networks are not available in the majority of cities. The considerable potential of using such indicators in urban planning and management offers an unprecedented opportunity for making the appropriate decisions for both daily urban planning and climate change mitigation and adaptation. EO-based indicators such as those presented in Figures 1-4 have the potential to lead to next generation urban information services, capable of supporting the implementation of urban planning initiatives, towards a better quality of life in cities.

Sustainable urban planning must focus on assuring a better quality of life in cities, which highly depends on applying the expert knowledge and scientific findings to urban plans and motivations. The proposed EO-based indicators framework has great potential to support sustainable urban planning, if urban planners and policy makers take into account the information provided by such indicators in their day to day activities.

\section{Author Contributions}

Individual contribution of each co-author to the reported research: Nektarios Chrysoulakis was the GEOURBAN project Coordinator and involved in indicators development, in CoP development in the three cities and in satellite data analysis for indicators evaluation. Christian Feigenwinter was involved in $\mathrm{CoP}$ development in Basel, in analysis of $\mathrm{CoP}$ results and in satellite data analysis for indicators evaluation. Dimitrios Triantakonstantis was involved in analysis of CoP results and in satellite data analysis for indicators evaluation. Igor Penyevskiy was responsible for the CoP development in Tyumen and was involved in analysis of $\mathrm{CoP}$ results. Abraham Tal was responsible for the CoP development in Tel Aviv and was involved in analysis of CoP results. Eberhard Parlow was responsible for the CoP development in Basel and was involved in analysis of CoP results, as well as in satellite data analysis for indicators evaluation. Guy Fleishman was involved in CoP development in Tel Aviv and in analysis of CoP results. Sebnem Düzgün was involved in satellite data pre-processing, as well as in satellite data processing for indicators evaluation in all case studies. Thomas Esch was 
involved in indicators development and in satellite data analysis for indicators evaluation in all case studies. Mattia Marconcini was involved in satellite data pre-processing, as well as in satellite data processing for indicators evaluation in all case studies.

\section{Conflicts of Interest}

The authors declare no conflict of interest.

\section{References}

1. United Nations Population Prospect. World Population Prospects-The 2008 Revision; United Nations Population Prospect: New York, NY, USA, 2008.

2. Campbell, S. Green cities, growing cities, just cities? Urban planning and the contradictions of sustainable development. J. Am. Plan. Assoc. 1996, 62, 296-312.

3. Shen, L.Y.; Ochoa, J.; Shah, M.N.; Zhang, X. The application of urban sustainability indicators-A comparison between various practices. Habitat Int. 2011, 35, 17-29.

4. Zhang, X.; Wu, Y.; Shen, L. An evaluation framework for the sustainability of urban land use: A study of capital cities and municipalities in China. Habitat Int. 2011, 35, 141-149.

5. Chrysoulakis, N.; Lopes, M.; San José, R.; Grimmond, C.S.B.; Jones, M.B.; Magliulo, V.; Klostermann, J.E.M.; Synnefa, A.; Mitraka, Z.; Castro, E.; et al. Sustainable urban metabolism as a link between bio-physical sciences and urban planning: The BRIDGE project. Landsc. Urban Plan. 2013, 112, 100-117.

6. González, A.; Donnelly, A.; Jones, M.; Chrysoulakis, N.; Lopes, M. A decision-support system for sustainable urban metabolism in Europe. Environ. Impact Assess. Rev. 2013, 38, 109-119.

7. Taubenböck, H.; Esch, T. Remote Sensing-An Effective Data Source for Urban Monitoring. Earth Observation, Urban Monitoring, 20 July 2011.

8. Barnsley, M.J.; Barr, S.L. Monitoring urban land use by earth observation. Surv. Geophys. 2000, 21, 269-289.

9. Huang, J.; Lu, X.X.; Sellers, J.M. A global comparative analysis of urban form: Applying spatial metrics and remote sensing. Landsc. Urban Plan. 2007, 82, 184-197.

10. Esch, T.; Thiel, M. How can Earth Observation Support the Sustainable Development of Urban Environments? Urban Remote Sensing. In Proceedings of the 46th ISOCARP Congress, Nairobi, Kenya, 19-23 September 2010; pp. 1-13.

11. Huang, S.L.; Wong, J.H.; Chen, T.C. A framework of indicator system for measuring Taipei's urban sustainability. Landsc. Urban Plan. 1998, 42, 15-27.

12. Esch, T.; Taubenböck, H.; Chrysoulakis, N.; Düzgün, H.S.; Tal, A.; Feigenwinter, C.; Parlow, E. Exploiting Earth Observation in Sustainable Urban Planning and Management-The GEOURBAN Project. In Proceedings of the Joint Urban Remote Sensing Event JURSE, Sao Paulo, Brazil, 21-23 April 2013.

13. Kottek, M.; Grieser, J.; Beck, C.; Rudolf, B.; Rubel, F. World map of the Köppen-Geiger climate classification updated. Meteorol. Z. 2006, 15, 259-263. 
14. Chrysoulakis, N. Estimation of the all-wave net radiation balance in urban environment with the combined use of Terra/ASTER multispectral imagery and in-situ spatial data. J. Geophys. Res. 2003, 108, 4582, doi:10.1029/2003JD003396.

15. Frey, C.M.; Parlow, E. Geometry effect on the estimation of band reflectance in an urban area. Theor. Appl. Climatol. 2009, 96, 395-406.

16. Keramitsoglou, I.; Daglis, I.A.; Amiridis, V.; Chrysoulakis, N.; Ceriola, G.; Manunta, P.; Maiheu, B.; de Ridder, K.; Paganini, M. Evaluation of satellite-derived products for the characterization of the urban thermal environment. J. Appl. Remote Sens. 2012, 6, 061704.

17. Lu, D.; Weng, Q. A survey of image classification methods and techniques for improving classification performance. Int. J. Remote Sens. 2007, 28, 823-870.

18. Lu, D.; Mausel, P.; Brondízio, E.; Moran, E. Change detection techniques. Int. J. Remote Sens. 2004, 25, 2365-2401.

19. Mitraka, Z.; Chrysoulakis, N.; Kamarianakis, Y.; Partsinevelos, P.; Tsouchlaraki, A. Improving the estimation of urban surface emissivity based on sub-pixel classification of high resolution satellite imagery. Remote Sens. Environ.2012, 117, 125-134.

20. North, P.; Grey, W.; Heckel, A.; Fischer, J.; Preusker, R.; Brockmann, C. MERIS/AATSR Synergy Algorithms for Cloud Screening, Aerosol Retrieval, and Atmospheric Correction. Algorithm Theoretical Basis Document Land Aerosol and Surface Reflectance ATBD; ESRIN Contract No. 21090/07/I-LG; European Space Agency: Frascati, Italy, 2009.

21. Toutin, T. Elevation modeling from satellite visible and infrared (VIR) data. Int. J. Remote Sens. 2001, 22, 1097-1125.

22. Esch, T.; Thiel, M.; Schenk, A.; Roth, A.; Müller, A.; Dech, S. Delineating of urban footprints from TerraSAR-X data by analyzing speckle characteristics and intensity information. IEEE Trans. Geosci. Remote Sens. 2010, 48, 905-916.

23. Wurm, M.; Taubenböck, H.; Schardt, M.; Esch, T.; Dech, S. Object-based image information fusion using multisensor Earth observation data over urban areas. Int. J. Image Data Fusion 2011, 2, 121-147.

24. Wong, C. Determining factors for local economic development: The perception of practitioners in the north west and eastern regions of the UK. Reg. Stud. 1998, 32, 707-720.

25. González, A.; Donnelly, A.; Jones, M.; Klostermann, J.; Groot, A.; Breil, M. Community of practice approach to developing urban sustainability indicators. J. Environ. Assess. Policy Manag. 2011, 13, 1-27.

26. Kanaroglou, P.S.; Soulakellis, N.A.; Sifakis, N.I. Improvement of satellite derived pollution maps with the use of a geostatistical interpolation method. J. Geogr. Syst. 2002, 4, 193-208.

27. Benas, N.; Beloconi, A.; Chrysoulakis, N. Urban PM Estimation Based on MERIS/AATSR Synergy Derived AOT and MODIS Level-2 Atmospheric Parameters. In Proceedings of the 3rd MERIS/(A)ATSR and OCLI-SLSTR (Sentinel-3) Preparatory Workshop, ESA-ESRIN, Frascati, Italy, 15-19 October 2012; pp. 111-112.

28. Lee, H.Y.; Kim, T.; Park, W.; Lee, H.K. Extraction of digital elevation models from satellite stereo images through stereo matching based on epipolarity and scene geometry. Image Vis. Comput. 2003, 21, 789-796. 
29. Zhang, C.; Fraser, C. Generation of digital surface model from high resolution satellite imagery. Int. Arch. Photogramm. Remote Sens. Spat. Inf. Sci. 2008, 37, 785-790.

30. Wu, S.; Qiu, X.; Wang, L. Population estimation methods in GIS and remote sensing: A review. GISci. Remote Sens. 2005, 42, 80-96.

31. Qiu, F.; Woller, K.L.; Briggs, R. Modeling urban population growth from remotely sensed imagery and tiger GIS road data. Photogramm. Eng. Remote Sens. 2003, 69, 1031-1042.

32. Wurm, M.; Taubenböck, H.; Krings, S.; Birkmann, J.; Roth, A.; Dech, S. Derivation of Population Distribution for Vulnerability Assessment in Flood-Prone German Cities Using Multisensoral Remote Sensing Data; SPIE Europe: Berlin, Germany, 2009.

33. Lopes, C.; Adnot, J.; Santamouris, M.; Klitsikas, N.; Alvarez, S.; Sanchez, F. Managing the Growth of the Demand for Cooling in Urban Areas and Mitigating the Urban Heat Island Effect. In Proceedings of the ECEEE Congress, Mandelieu, France, 11-16 June 2001; Volume II.

34. Huq, S.; Kovats, S.; Reid, H.; Satterthwaite, D. Editorial: Reducing risks to cities from disasters and climate change. Environ. Urban 2007, 19, 3-15.

35. Hammer, A.; Heinemann, D.; Hoyer, C.; Kuhlemann, R.; Lorenz, E.; Müller, R.; Beyer, H.G. Solar energy assessment using remote sensing technologies. Remote Sens. Environ. 2003, 86, $423-432$.

36. Yu, B.; Liu, H.; Wu, J.; Lin, W.M. Investigating impacts of urban morphology on spatio-temporal variations of solar radiation with airborne LIDAR data and a solar flux model: A case study of downtown Houston. Int. J. Remote Sens. 2009, 30, 4359-4385.

37. Lindberg, F.; Grimmond, C.S.B. Continuous sky view factor from high resolution urban digital elevation models. Clim. Res. 2010, 42, 177-183.

38. Ioncica, M.; Petrescu, E.C.; Ioncica, D. Transports and consumers' ecological behavior. Amfiteatru Econ. 2012, 14, 70-83.

39. Jin, X.; Davis, C.H. An integrated system for automatic road mapping from high-resolution multi-spectral satellite imagery by information fusion. Inf. Fusion 2005, 6, 257-273.

40. Mena, J.B.; Malpica, J.A. An automatic method for road extraction in rural and semi-urban areas starting from high resolution satellite imagery. Pattern Recognit. Lett. 2005, 26, 1201-1220.

41. Voogt, J.; Oke, T. Thermal remote sensing of urban climates. Remote Sens. Environ. 2003, 86, 370-384.

42. Small, C. Comparative analysis of urban reflectance and surface temperature. Remote Sens. Environ. 2006, 104, 168-189.

43. Weng, Q. Thermal infrared remote sensing for urban climate and environmental studies: Methods, applications, and trends. ISPRS J. Photogramm. Remote Sens. 2009, 64, 335-344.

44. Schaaf, C.B.; Gao, F.; Strahler, A.H.; Lucht, W.; Li, X.; Tsang, T.; Strugnell, N.C.; Zhang, X.; Jin, Y.; Muller, J.P.; et al. First operational BRDF, albedo nadir reflectance products from MODIS. Remote Sens. Environ. 2002, 83, 135-148.

45. Frey, C.; Parlow, E. Flux measurements in Cairo. Part 2: On the determination of the spatial radiation and energy balance using ASTER satellite data. Remote Sens. 2012, 4, 2635-2660.

46. Liang, S. Narrowband to broadband conversions of land surface albedo I Algorithms. Remote Sens. Environ. 2000, 76, 213-238. 
47. Zhang, J.; Foody, G.M. Fully-fuzzy supervised classification of sub-urban land cover from remotely sensed imagery: Statistical and artificial neural network approaches. Int. J. Remote Sens. 2001, 22, 615-628.

48. Zhang, Q.J.; Gong, P.; Shi, P. Study of urban spatial patterns from SPOT panchromatic imagery using textural analysis. Int. J. Remote Sens. 2003, 24, 4137-4160.

49. Herold, M.; Mueller, S.; Guenter, S.; Scepan, J. Object-Oriented Mapping and Analysis of Urban Land Use/Cover Using IKONOS Data. In Geoinformation for European-Wide Integration, Proceedings of the 22nd EARSEL Symposium, Prague, Czech Republic, 4-6 June 2002; IOS Press: Amsterdam, The Netherlands, 2002; pp. 531-538.

50. Lu, D.; Weng, Q. Use of impervious surface in urban land-use classification. Remote Sens. Environ. 2006, 102, 146-160.

51. Jat, M.K.; Garg, P.K.; Khare, D. Monitoring and modeling of urban sprawl using remote sensing and GIS techniques. Int. J. Appl. Earth Obs. Geoinf. 2008, 10, 26-43.

52. Powell, R.; Roberts, D.; Dennison, P.; Hess, L. Sub-pixel mapping of urban land cover using multiple endmember spectral mixture analysis: Manaus, Brazil. Remote Sens. Environ. 2007, 106, 253-267.

53. Rees, W.G. Comparing the spatial content of thematic Maps. Int. J. Remote Sens. 2008, 29, 3833-3844

54. Pacifici, F.; Chini, M.; Emery, W.J. A neural network approach using multi-scale textural metrics from very high-resolution panchromatic imagery for urban land-use classification. Remote Sens. Environ. 2009, 113, 1276-1292.

55. Mountrakis, G.; Im, J.; Ogole, C. Support vector machines in remote sensing: A review. ISPRS J. Photogramm. Remote Sens. 2011, 66, 247-259.

56. Bruzzone, L.; Chi, M.; Marconcini, M. A novel transductive SVM for the semisupervised classification of remote sensing images. IEEE Trans. Geosci. Remote Sens. 2006, 44, 3363-3373.

57. Mari, M.J.; Bovolo, F.; Comez-Chova, L.; Bruzzone, L.; Camps-Valls, G. Semisupervised one-class support vector machines for classification of remote sensing data. IEEE Trans. Geosci. Remote Sens. 2010, 48, 3188-3197.

58. Camps-Valls, G.; Marsheva, T.B.; Zhou, D. Semi-supervised graph-based hyperspectral image classification. IEEE Trans. Geosci. Remote Sens. 2007, 45, 3044-3054.

59. Small, C. Estimation of urban vegetation abundance by spectral mixture analysis. Int. J. Remote Sens. 2001, 22, 1305-1334.

60. Verrelst, J. Space-Born Spectro-Directional Estimation of Forest Properties. Ph.D. Thesis, Wageningen University, Wageningen, The Netherlands, 2010.

61. Chrysoulakis, N.; Flouri, E.; Diamandakis, E.; Dougalis, V.; Synolakis, C.E.; Foteinis, S. Remote Sensing in Support of Tsunami Mitigation Planning in the Mediterranean. In Proceedings of the 1st International Conference on Remote Sensing Techniques in Disaster Management and Emergency Response in the Mediterranean Region, Zadar, Croatia, 22-24 September 2008. 
62. Taubenböck, H.; Goseberg, N.; Setiadi, N.; Lämmel, G.; Moder, F.; Oczipka, M.; Klüpfel, H.; Wahl, R.; Schlurmann, T.; Strunz, G.; et al. Last-mile preparation for a potential disaster-Interdisciplinary approach towards tsunami early warning and an evacuation information system for the coastal city of Padang, Indonesia. Nat. Hazards Earth Syst. Sci. 2009, 9, 1509-1528.

63. Grubler, A.; Bai, X.; Buettner, T.; Dhakal, S.; Fisk, D.; Ichinose, T.; Keirstead, J.; Sammer, G.; Satterthwaite, D.; Schulz, N. Urban Energy Systems. In Global Energy Assessment: Toward a Sustainable Future; Gomez-Echeverri, L., Johansson, T.B., Nakicenovic, N., Patwardhan, A. Eds.; Cambridge University Press: Cambridge, UK/New York, NY, USA; IIASA: Laxenburg, Austria, 2012; pp. 1307-1400.

64. EEA. Urban Adaption to Climate Change in Europe: Challenges and Opportunities for Cities Together with Supportive National and European Policies; European Environment Agency Report 2/2012; European Environment Agency: Copenhagen, Denmark, 2012.

65. Scavia, D.; Field, J.; Boesch, D.; Buddemeier, R.; Burkett, V.; Cayan, D.; Fogarty, M.; Harwell, M.A.; Howarth, R.W.; Mason, C. Climate change impacts on U.S. coastal and marine ecosystems. Estuaries 2002, 25, 149-164.

66. Martin, D.; Bélanger, D.; Gosselin, P.; Brazeau, J.; Furgal, C.; Déry, S. Drinking water and potential threats to human health in Nunavik: Adaptation strategies under climate change conditions. Arctic 2007, 60, 195-202.

67. Minnett, P.J. Satellite Remote Sensing: Sea Surface Temperatures. In Encyclopedia of Ocean Sciences; Steele, J., Thorpe, S., Turekian, K., Eds.; Academic Press: London, UK, 2001; pp. 2552-2563.

68. Corburn, J. Cities, climate change and urban heat island mitigation: Localising global environmental science. Urban Stud. 2009, 46, 413-427.

69. Stone, B. Land use as climate change mitigation. Environ. Sci. Technol. 2009, 43, 9052-9056.

70. Dousset, B.; Gourmelon, F.; Laaidi, K.; Zeghnoun, A.; Giraudet, E.; Bretin, P.; Mauri, E.; Vandentorren, S. Satellite monitoring of summer heat waves in the Paris metropolitan area. Int. J. Climatol. 2011, 31, 313-323.

71. Fernandes, R.; Fraser, R.; Latifovic, R.; Cihlar, J.; Beaubien, J.; Du, Y. Approaches to fractional land cover and continuous field mapping: A comparative assessment over the BOREAS study region. Remote Sens. Environ. 2004, 89, 234-251.

72. Scanlon, T.M.; Albertson, J.D.; Caylor, K.K.; Williams, C.A. Determining land surface fractional cover from NDVI and rainfall time series for a savanna ecosystem. Remote Sens. Environ. 2002, $82,376-388$.

73. Seto, K.C.; Güneralp, B.; Hutyra, L. Global forecasts of urban expansion to 2030 and direct impacts on biodiversity and carbon pools. Proc. Natl. Acad. Sci. USA 2012, 109, 16083-16088.

74. Stone, B.; Vargo, J.; Habeeb, D. Managing climate change in cities: Will climate action plans work? Lands. Urban Plan. 2012, 107, 263-271.

(C) 2014 by the authors; licensee MDPI, Basel, Switzerland. This article is an open access article distributed under the terms and conditions of the Creative Commons Attribution license (http://creativecommons.org/licenses/by/3.0/). 